\title{
PENGARUH APLIKASI PEMBELAJARAN BERBASIS ALAM SEKITAR TERHADAP HASIL BELAJAR BIOLOGI SISWA KELAS VIII SMP N 10 KABUPATEN SORONG
}

\section{MUHAMMAD KASDIN, ANANG TRIYOSO, SIROJJUDIN}

\author{
P-Biologi STKIP Muhammadiyah Sorong
}

Email: Muhammadkasdin66@mail.com

\begin{abstract}
ABSTRAK
Penelitian ini bertujuan untuk mengetahui pengaruh pembelajaran biologi menggunakan pembelajaran berbasis alam sekitar sekolah sebagai aplikasi pembelajaran. Penelitian dilaksanakan di SMP N 10 Kabupaten Sorong pada bulan Mei 2016, dengan mengunakan populasi yang berjumlah 40 siswa. Sampel yang digunakan berjumlah 20 siswa untuk kelas VIIIA dan 20 siswa untuk kelas VIIIB. Metode penelitian yang digunakan adalah penelitian eksperimen. deskriptif kuantitatif dengan analisis komperatif. Instrumen yang digunakan adalah tes, yang sebelumnya diuji validitas dan uji reliabilitas. Hasil uji validitas pada instrumen yang digunakan valid. Data tes berdistribusi homogen dan semua normal. Hasil uji $t$-test paired sampel kelas VIIIA yakni thitung > ttabel $(0,401<$ 2,09 ) dan kelas VIIIB thitung > ttabel $(15,884>2,10092)$ sehingga ada perbedaan pada hasil belajar siswa sebelum dan sesudah melakukan pembelajaran menggunakan pembelajaran berbasis alam sekitar sekoalah lingkungan alam sekitar sekolah sebagai aplikasi pembelajaran dan dari hasil tes siswa yang diperoleh bahwa aplikasi pembelajaran tersebut efektif sebagai aplikasi pembelajaran.
\end{abstract}

Kata kunci: Hasil Belajar, Pembelajaran Berbasis Lingkungan Sekitar,Biologi, SMP N10 Kabupaten Sorong

\section{ABSTRACK}

This research aims to know the influence of biology learning using natural environment based learning as a learning method. This research was conducted at SMP N 10 Sorong Regeney on May 2016 with the population was 40 students. The sample of this research was 20 students which then used as exsperiment class. This research was quantitative descriptive research that used comparative analysis. The instrument on this research was a test which has been tested its validity and reliability and the result of the test was valid. The distribution of the tested data was homogoneus and normal. The t-test paired sample result on VIIIA grade was thitung > ttabel $(0,401<$ 2,09) and the result on VIIIB grade was thitung > ttabel (15,884 > 2,10092).Based on the result, it could be concluded that there was a significant distinction on students' learning result before and after applying natural environment based learning on school environment.Based on the students' test result, it showed that the application of natural enviromentbased learning was effective to be used as learning method on teaching Biology subject.

Keywords: students' learning result, natural environmentbased learning, biology,SMP N 10 Sorong Regensy

\section{Pendahuluan}

Undang-Undang Republik Indonesia No. 20 tahun 2003 pasal 1 ayat 1 tentang Sistem Pendidikan Nasional (SISDIKNAS) menyebutkan bahwa "pendidikan adalah usaha sadar dan terencana untuk dapat mewujudkan suasana belajar dan proses pembelajaran agar siswa secara aktif mengembangkan potensi dirinya untuk memiliki kekuatan spiritual keagamaan, pengendalian diri, kepribadian, kecerdasan, akhlak mulia, serta keterampilan yang diperlukan dirinya, masyarakat, bangsa dan negara". Depdiknas (dalam Ningsih dkk, 2014 :5).

Pendidikan memiliki dua aspek pembelajaran yang paling menonjol yakni metode dan media pembelajaran sebagai alat bantu mengajar. Media pembelajaran dapat dikategorikan sebagai faktor eksternal yang ikut mempengaruhi proses pembelajaran di kelas, baik pa da diri pengajar maupun pembelajar. Berdasarkan hasil penelitian menunjukkan bahwa pengetahuan seseorang diperoleh dari pengalaman pendengaran $11 \%$, dari pengalaman penglihatan $83 \%$. Sedangkan kemampuan daya ingat yaitu berupa pengalaman yang diperoleh dari apa yang didengar 20\%, dari pengalaman apa yang dilihat 50\%. Arief, (dalam wahyudin dkk, 2010)

Santyasa (2009:2) menyebutkan bahwa Peserta didik akan memperoleh pengalaman nyata serta dapat memadukan antara teori dan kondisi nyata yang ada di lapangan, sehingga mudah diingat dan akan melekat kuat dan tahan lama dalam diri peserta didik. Di samping itu suasana akan lebih segar dan tentunya akan menarik peserta didik untuk terus mencari dan menemukan sesuatu, di mana peserta didik diajak untuk menemukan sesuatu dan menyimpulkan konsep sendiri. Diharapkan dengan model ini peserta didik akan menghargai proses pencarian dan penemuan, sehingga pembelajaran akan lebih berkualitas dan bermakna 
(Santyasa, 2009)

Badan Standar Nasional Pendidikan (2006) Biologi sebagai salah satu bidang IPA menyediakan berbagai pengalaman belajar untuk memahami konsep dan proses sains, sehingga siswa perlu dibantu untuk mengembangkan keterampilan proses supaya mereka mampu menjelajahi dan memahami alam sekitar. Untuk dapat mengembangkan keterampilan proses siswa, dibutuhkan cara pembelajaran yang mengutamakan kepada aktivitas belajar siswa, karena pada prinsipnya belajar adalah berbuat.

Dimyati dan Mudjiono (2009), hasil belajar merupakan tujuan akhir dilaksanakannya kegiatan pembelajaran di sekolah. Hasil belajar dapat ditingkatkan melalui usaha sadar yang dilakukan secara sistematis mengarah kepada perubahan yang positif yang kemudian disebut dengan proses belajar. Akhir dari proses belajar adalah perolehan suatu hasil belajar siswa. Hasil belajar siswa di kelas terkumpul dalam himpunan hasil belajar kelas. Semua hasil belajar tersebut merupakan hasil dari suatu interaksi tindak belajar dan tindak mengajar. Dari sisi guru, tindak mengajar di akhiri dengan proses evaluasi hasil belajar, sedangkan dari sisi siswa, hasil belajar merupakan berakhirnya penggal dan puncak proses belajar.

Menurut Hamalik, (2007) proses belajar adalah dalam rangka mempengaruhi siswa agar dapat menyesuaikan terhadap diri sendiri maupun dengan lingkungannya supaya menimbulkan perubahan dalam dirinya yang memungkinkan berfungsi dalam kehidupan masyarakat.

Berdasarkan hasil observasi peneliti pada SMP NEGERI 10 kabupaten Sorong memiliki keterbatasan pembelajaran pada media lingkungan alam sekitar, kebanyakan para guru selalu menjadikan ruang kelas sebagai tempat satu-satunya media untuk melaksanakan proses pembelajaran. Hal ini membuat para siswa cepat merasa bosan saat menerima pelajaran yang telah diberikan oleh guru.

Lingkungan yang dimanfaatkan dalam kegiatan pembelajaran disekolah adalah semua jenis lingkungan yang sesuai dengan kompelensi atau tujuan pembelajaran yang harus dicapai, serta bahan ajar yang akan disampaikan kepada peserta didik.Jenis lingkungan tersebut berupa lingkungan sosial maupunlingkungan alam atau lingkungan fisik.

Hasil belajar sebagai perubahan-perubahan yang terjadi pada diri siswa, baik yang menyangkut aspek kognitif, afektif, dan psikomotor sebagai hasil dari kegiatan belajar, dengan media yang digunakan dalam penelitian ini adalah media pembelajaran berbasis alam di SMP NEGERI 10 Kabupaten Sorong.

Berdasarkan latar belakang di atas dimana pembelajaran biologi dengan alam memiliki hubungan dengan pengaruh hasil belajar siswa maka peneliti akan meneliti tentang "Pengaruh Aplikasi Pembelajaran Berbasis Alam Sekitar Terhadap Hasil Belajar Biologi Siswa kelas VIII" di SMP NEGERI 10,
Kabupaten Sorong. Tujuan penelitian ini adalah untuk mengetahui pengaruh pembelajaran biologi menggunakan lingkungan alam sekitar sekolah sebagai media pembelajaran untuk siswa kelas VIII di SMP NEGERI 10 Kabupaten Sorong

\section{Metode Penelitian}

Pada penelitian ini, peneliti menggunakan pendekatan kuantitatif, (Sugiono dalam Nurlily, 2014) mengatakan bahwa pendekatan kuantitatif yaitu suatu proses menemukan pengertian menggunakan data berupa angka sebagai alat untuk menemukan keterangan mengenai apa yang ingin diketahui.

Dalam penelitian ini menggunakan desain eksperimental semu (Quasi Experimental Designs) dalam bentuk The Nonequeivalent Control group Design.

\begin{tabular}{|l|l|l|l|}
$\begin{array}{l}\text { Kelas } \\
\text { experimen }\end{array}$ & 01 & $\mathrm{X}$ & 03 \\
\hline $\begin{array}{l}\text { Kelas } \\
\text { kontrol }\end{array}$ & 02 & $\mathrm{Y}$ & 04 \\
\hline
\end{tabular}

Emzir, (2012)

Keterangan:

01: Pretest Kelas Eksperimen

02 :Postest Kelas Eksperimen

03 : Pretest Kelas Kontrol

04 : Postest Kelas Kontrol

$\mathrm{X}$ : Perlakuan menggunakan aplikasi berbasis alam sekitar

Y : Perlakuan menggunakan aplikasi Ceramah

Penelitian ini diaksanakan di SMP NEGERI 10 KABUPATEN SORONG pada tanggal 15 mei 2016 hingga selesai.

Sampel adalah bagian dari jumlah dan karakteristik yang dimiliki oleh populasi. Penelitian ini menggunakan sampel pada kelas VIII di SMP N 10 Kabupaten Sorong.

Arikunto (dalam yulianti, 2011) metode tes merupakan sejumlah pertanyaan atau latihan serta alat yang lain untuk mengatur keterampilan, pengetahuan, kemampuan atau bakat yang dimiliki oleh individu/kelompok. Arikunto (dalam yulianti, 2011), tes digunakan untuk memperoleh data tentang hasil belajar. Bentuk tes yang digunakan berupa tes obyektif (esay) dengan jumlah 7 soal dan diberikan setelah perlakuan.

\subsubsection{Observasi}

Sudijono (dalam yulianti, 2011), metode observasi merupakan cara menghimpun bahan-bahan keterangan (data) yang dilakukan dengan mengadakan pengamatan dan pencatatan secara sistematis terhadap fenomena-fenomena yang sedang dijadikan sasaran pengamatan. Metode ini digunakan untuk memperoleh data tentang keadaan dan fasilitas yang ada, mengamati segala kejadian yang berhubungan dengan keefektifan pembelajaran biologi menggunakan lingkungan alam sekitar sekolah sebagai media pembelajaran.

\subsubsection{Dokumentasi}


S. Margono (dalam yulianti, 2011) metode dokumentasi merupakan metode yang digunakan untuk mencari data melalui peninggalan tertulis, seperti arsip dan termasuk juga buku-buku tentang pendapat, teori dan lain-lain yang berhubungan dengan masalah penelitian. Metode ini digunakan untuk memperoleh data berupa jumlah dan nama-nama peserta didik serta hal-hal lain.

1. Melakukan observasi dan penentuan sekolah tempat penelitian

2. Mengurus surat ijin penelitian kepada sekolah sekolah yang akan diteliti

3. Melakukan observasi kepada siswa disekolah tempat penelitian

Penelitian ini dilaksanakan di sekolah SMP Negeri

10 Kabupaten Sorong, pada tanggal 15-25 mei 2016

Data yang terkumpul dalam penelitian ini dianalisis dengan menggunakan aplikasi SPSS 20 untuk mempermudah penelitian dalam perhitungan. Teknik analisis data pada penelitian ini dapat dibagi menjadi :

Uji homogentitas dilakukan untuk mengetahui perbedaan atara dua kelompok atau populasi memiliki tingkat varian yang sama atau tidak, uji homogenitas yang digunakan adalah uji Fisher

Uji normalitas data dimaksudkan untuk memperlihatkan bahwa data sampel berasal dari populasi yang berdistribusi normal. Ada beberapa teknik yang dapat digunakan untuk menguji normalitas data, antara lain uji chi-kuadrat, uji lilliefors, dan uji kolmogorov-smirnov.

Metode Chi-Square atau X2 untuk Uji Goodness of fit Distribusi Normal menggunakan pendekatan penjumlahan penyimpangan data observasi tiap kelas dengan nilai yang diharapkan. Persyaratan Metode Chi Square (Uji Goodness of fit Distribusi Normal)

Validitas adalah suatu ukuran yang menunjukkan tingkat kevalidan atau kesahihan suatu instrument. Sebuah item dikatakan valid apabila mempunyai dukungan yang besar terhadap skor total. Skor pada item menyebabkan skor total menjadi tinggi atau rendah. Uji validitas digunakan untuk menentukan validitas item soal menggunakan rumus korelasi product moment.

Reliabilitas (Reliability, keterpercayaan) menunjuk pada pengertian apakah sebuah instrument dapat mengukur sesuatu yang diukur secara konsisten dari waktu ke waktu.Jadi, kata kunci untuk syarat kualifikasi suatu instrumen

\section{Pembahasan}

Data hasil penelitian ini diperoleh dari peelitian yang diterapkan pada Sekolah Menengah Pertama (SMP) yang berada di Distrik Klamesen kabupaten sorong, dengan mengambil dua kelas dan masing-masing kelas merupakan kelas eksperimendan kelas kontrol yakni SMP Negeri 10 Kabupaten Sorong.

Data penelitian ini berupa tes awal dan tes akhir siswa yang diberlakukan pada kedua kelas eksperimen untuk mengetahui efektivitas penggunaan media,test awal dilakukan sebelum siswa diberi perlakuan dan untuk mengetahui hasil belajar siswa setelah diberi perlakuan maka peneliti memberikan tes akhir.

Hasil tes sebelum dan sesudah perlakuan yang diberikan kepada masing-masing kelas berupa tes uraian, berikut adalah deskripsi data skor siswa pada masing-masing kelas:

Hasil analisis dari instrumen soal menunjukan bahwa 5 dari 7 soal dinyatakan valid, sedangkan 2 soal yang dinyatakan tidak valid akan dirubah sebelum digunakan sebagai instrumen. Selain itu uji reliabilitas diperoleh hasil yang reliable, sehingga dapat digunakan juga sebagai instrumen.

Hasil uji homogenitas sampel siswa kelas VIIIA dan kelas VIIIB adalah homogen. Maka hasil uji homogenitas tersebut dapat digunakan sebagai data penelitian.

Uji normalitas menyatakan bahwa tidak semua data berdistribusi normal, namun pada saat pengujian prasyarat homogenitas semua data dinyatakan homogen, maka uji hipotesis yang digunakan adalah uji t-test paired sampel.

Hasil penelitian siswa kelas VIIIA diperoleh fakta berdasarkan uji hipotesis adalah thitung $=14,168$. Jika dibandingkan dengan ttabel $=2,09302$ dengan df 19 maka hasil yang diperoleh yakni thitung $=14,168>$ ttabel = 2,09302 yang menunjukan bahwa H1 diterima, artinya ada perbedaan terhadap hasil pembelajaran menggunakan media lingkungan alam sekitar sekolah sebagai media pembelajaran, hasil dapat dilihat pada distribusi frekuensi skor awal siswa pada tabel 4.2 yang menyatakan bahwa dari 20 siswa yang memperoleh nilai diatas rata-rata 51.50 sebanyak $50 \%$. Hasil skor awal siswa dapat juga dilihat pada gambar 4.1 grafik distribusi frekuensi skor awal siswa. Setelah mendapat perlakuan siswa diberikan test akhir dan hasil menunjukan bahwa dari 20 siswa yang memperoleh hasil diatas rata-rata 76.05 sebanyak $90 \%$ dapat dilihat pada tabel 4.5 .

Uji normalitas data tes awal siswa kelas VIIIA diperoleh hasil berdasarkan rumus Kolmogorov-Smirnov signifikasi 0,026 < 0,05 dan pada uji normalitas data test akhir siswa kelas VIIIA diperoleh hasil berdasarkan rumus Kolmogrov-Smirnov signifikan $0,000<0,05$ maka dapat disimpulkan bahwa tersebut berdistribusi tidak normal, pada saat uji homogenitas test awal dan tes akhir siswa kelas VIIIA memiliki varian data homogen.

Hasil penelitian siswa kelas VIIIB diperoleh fakta berdasarkan uji hipotesis bahwa nilai thitung $=15,884$. Jika dibandingkan dengan ttabel $=2,10092$ maka hasil yang diperoleh adalalah thitung $=15,884>$ ttabel $=$ 2,10092 yang menunjukan bahwa H1 diterima, artinya ada perbedaan terhadap hasil pembelajaran menggunakan media lingkungan alam sekitar sekolah sebagai media pembelajaran, hasil dapat dilihat pada distribusi frekuensi skor awal siswa pada tabel 4.3 yang 
menyatakan bahwa dari 20 siswa yang memperoleh nilai diatas rata-rata 56.75 sebanyak $55 \%$. Hasil skor awal siswa dapat juga dilihat pada gambar 4.2 grafik distribusi frekuensi skor awal siswa. Setelah mendapat perlakuan siswa diberikan tes akhir dan hasil menunjukan bahwa dari 20 siswa yang memperoleh hasil diatas rata-rata 66.35 sebanyak $55 \%$ dapat dilihat pada tabel 4.6. Hasil skor awal siswa dapat juga dilihat pada gambar 4.4 grsfik distribusi frekuensi skor akhir siswa.

Uji normalitas data tes awal siswa kelas VIIIB diperoleh hasil berdasarkan rumus Kolmogrov-Smirnov signifikan 0,142>0,05 dan pada tes akhir siswa kelas VIIIB diperoleh hasil berdasarkan rumus Kolmogorov-Smirnov signifikan 0,182 > 0,05 dengan demikian dapat disimpulkan bahwa data tersebut berdistribusi normal.

Mencermati upaya pengaruh pembelajaran yang sedangkan dikembangkan, para guru saat ini banyak ditawari dengan aneka pilihan aplikasi pembelajaran. Dari sekelian banyak aplikasi pembelajaran menurut peneliti bahwa APLIKASI PEMBELAJARAN BERBASIS ALAM SEKITAR adalah aplikasi yang tepat diterapkan pada matapelajaran ipa biologi. Karena aplikasi ini adalah pelaksanaan menitik pada pemecahan masalah.

Aplikasi pembelajaran berbasis alam sekitar, sekalipun beberapa kelemahan, seprti diperlukan waktu yang banyak, tetapi memiliki prinsip dan keunggulan-keunggulan yang berpusat pada penyelesaian masalah.

Keunggulan-keunggulan itu adalah:

1. Berpusat pada pemecahan masalah

2. Pengembangan berpikir kritis

3. Mengembangkan keterlibatan belajar

4. Mengembangkan kemampuan berpendapat

5. Mengembangkan rasa ingin tahu.

Keunggulan-keunggulan itulah aplikasi pembelajaran berbasis alam sekitar, mampu merubah situasi pembelajaran, sehingga dengan aplikasi tersebut guru mampu merubah suatu iliustrasi menjadi suatu contoh yang konkrit, memerikan banyak kesempatan siswa untuk mensimulasikan suatu konsep.

Dengan menggunakan metode ini, tiga dasar perilaku guru telah terpadu, tiga dasar iut adalah:

1. Prinsip keterlibatan siswa secara aktif

2. Mendorong siswa untuk menerima tanggung jawab untuk mendiagnosa perilakunya sendridan temannya sekelas

3. Kerja sama guru dan siswa berorientasi pada alternatif.

Metode pembelajaran ini juga menuntut siswa untuk memprakasai masalah secara bersama-sama dan member pemecahannya. Guru konsisten untuk tetap membimbing dan memimpin siswa dengan melalui tahapan yang berbeda. Walaupun demikian kepemimpinan tetap ada pada guru, sedangkan wewenang moral ada pada siswa.

\section{Kesimpulan}

Hasil penelitian dapat disimpulkan bahwa

1. Pada pembelajaran siswa kelas VIIIA hasil tes awal dan tes akhir siswa terdapat perbedaan, ini dibuktikan pada hasil hipotesis uji t-test paired sampel yang menunjukkan bahwa nilai thitung $=$

14,168. Jika dibandingkan dengan ttabel $=2,09302$, maka hasil yang diperoleh yakni thitung $=14,168>$ ttabel $=2,09302$ maka hipotesis yang diterima adalah nilai sebelum dan sesudah pemberlakuan aplikasi pembelajaran terdapat perbedaan atau tidak sama.

2. Pada pembelajaran siswa kelas VIIIB hasil tes awal dan tes akhir siswa terdapat perbedaan, ini dibuktikan pada hasil hipotesis uji t-test paired sampel yang menunjukkan bahwa nilai thitung = 15,884 . Jika dibandingkan dengan ttabel $=2,10092$, maka hasil yang diperoleh yakni thitung $=15,884>$ ttabel $=2,10092$ maka hipotesis yang ditterima adalah nilah sebelum dan sesudah pemberlakuan media pembelajaran terdapat perbedaan atau tidak sama.

Dengan demikian dapat disimpulkan bahwa penggunaan aplikasi pembelajaran berbasis alam sekitar sekolah tidak berpengaruh terhadap hasil belajar siswa, hal ini sesuai dengan hasil perhitungan menggunakan uji $t$ two sampel diperoleh hasil dari kedua kelas VIIIA dan kelas VIIIB thitung > ttabel.

\section{DAFTAR PUSTAKA}

[1] Achsin,(1986). Media Pendidikan daalam kegiatan belajar mengajar. Ujung

Pandang: Penerbit IKIP Ujung Pandang

[2] AECT. "The Definition of Educational Thecnologi”, 1977. Edisi Indonesia diterbitkan CV Rajawali dengan judul Definisi Teknologi Pendidikan

[3] Arikunto, Suharsimi. (2006). Dasar-Dasar Evaluasi Penelitian. Jakarta: Bumi Aksara.

[4] Arief S. Sadiman, dkk (1986) Media Pendidikan. CV,RAJAWALI

[5] Angkowo R \& Kosasi.(2007).Optimalisasi Media Pembelajaran.Jakarta:Grasindo BSNP, (2006). Standar isi untuk sistem pendidikan Dasar dan Menengah. Jakarta

Depertemen Pendidikan Nasional

[7] Damayanti dan Mudjiono, (2009). Efektifitas penggunaan media pembelajaran komputer untuk meningkatkan hasil belajar mata pelajaran ipa. Program pascasarjana Universitas Sebelas Maret

[9] Emzir. (2012). Metodologi penelitian pendidikan. Jakarta: PT. Raja Grafindo Persada

[10] Hamalik, (2006), Proses Belajar Mengajar, Bandung Bumi Aksara

[11] Mudjoo, (1999), Belajar dan Pembelajaran, Jakarta: Rineka Cipta 
[12] NURHASANAH,S. 2010. Pengaruh Pendekatan Reciprocal Teaching Terhadap Kemampuan Berfikir Kritis. Jakarta, Universitas Islam Negri SYARIF HIDAYATULLAH JAKARTA

[13] Ningsih dkk, (2014). Metode role playing untuk meningkatkan hasil belajar. Fakultas Keguruan dan Ilmu Pendidikan Universitas Lampung, Bandar Lampung. [14] Partino H.R.(2008).Metodologi Penelitian Kuantitatif. Yogyakarta: Pustaka Mahasiswa

[15] Peni susanti, (2008). Pembelajaran berbasis alam. STAIN, Salatiga.

[16] Undang - Undang Republik Indonesia No.20 Tahun 2003 tentang Sistem Pendidikan Nasiona

[17] UU NO. 22 Tahun 2003 tentang Sistem Pendidikan Nasional.

[18] Santyasa, (2009). Strategi Pembelajaran, Berorientasi Kepada Standar Proses Pendidikan, Jakarta: Kencana Prenada Media Grup
.[19] Siti Khasana.(2015). Efektivitas Media Lingkungan Sekitar Sekolah Terhadap Pembelajaran Biologi Siswa Kelas VIII SMP Negeri 5 Raja Ampat.Sorong:STKIP MUHAMMADIYAH SORONG Yatim Riyanto.2010.Metodologi Penelitian Pendidikan.Jakarta:SIC

[20] Sugiyono.(1999). Statistika untuk Penelitian.Bandung:Alfabeta

[21] Yatim Riyanto.2010. Metodologi Penelitian Pendidikan.Jakarta:SIC

[22] Yuyun Febrianti Nurlily, (2014). Efektivitas praktikum herbarium dalam pembelajaran biologi klasifikasi tanaman sayur-sayuran di SMP IT Nurul Yaqin. Sorong. STKIP Muhammadiyah Sorong [23] Wahyudin dkk, (2010). Pengembangan Kurikulum dan Pembelajaran. Jakarta , Universitas Terbuka [25] Webster,(Azhar Arsyad. 2015: 5), Media Pembelajaran, PT. RAJAGRAFINDO PERSADA, Jakarta 